\title{
Tim-3-mediated signaling in NK cells may be modulated by increased Galectin-9 expression in HIV-1 infection
}

\author{
S Jost", UY Moreno-Nieves, WF Garcia Beltran, K Rands, J Reardon, I Toth, A Piechocka-Trocha, BD Walker, \\ M Altfeld, MM Addo
}

From AIDS Vaccine 2012

Boston, MA, USA. 9-12 September 2012

\section{Background}

Natural Killer (NK) cells constitutively express high levels of Tim-3, an immunoregulatory molecule recently proposed to be a marker for mature and fully functional NK cells (Ndhlovu et al., 2012). Cytokines can induce Tim-3 expression on NK cells, and IFN-gamma production by Tim-3+ NK cells can be enhanced by exposure to Galectin-9 (Gleason et al. 2012), yet their ability to kill target cells is lost upon Tim-3 cross-linking. Moreover, up-regulation of Tim-3 on NK cells has been associated with reduced anti-viral properties in chronic hepatitis B infection (Ju et al., 2010). However, the impact of HIV-1 infection on Tim-3 expression on NK cells and on Tim-3-mediated NK cell function has not been studied yet.

\section{Methods}

Flow cytometry was used to analyze Tim-3 and intracellular galectin-9 expression in subjects with acute and chronic HIV-1 infection, in HIV-1 elite (VL $<50$ copies/ $\mathrm{ml}$ ) and viremic controllers (VL $<2000$ copies $/ \mathrm{ml}$ ), and in HIV-1 negative subjects. Plasma levels of Galectin-9 were quantified by ELISA.

\section{Results}

HIV-1 infection was associated with reduced expression of Tim-3 on NK cells, as early as in acute infection, and could be normalized by HAART. Importantly, percentages of Tim-3+ CD56 $6_{\text {dim }}$ NK cells correlated with CD4+ cell counts in untreated patients. Plasma concentrations of Galectin-9 were higher in HIV-1-infected individuals than in controls. Interestingly, Galectin-9 expression in immune

Ragon Institute of MGH, MIT and Harvard, Boston, MA, USA cells was significantly elevated in acute infection, with monocytes and dendritic cells displaying the highest levels, which correlated with viral loads. In vitro, Galectin-9 triggered NK cell activation and Tim-3 down-regulation on NK cells.

\section{Conclusion}

Further investigations are warranted to determine whether increased Galectin-9 production alters Tim-3 function and contributes to NK cell impaired activity in chronic HIV-1 infection. Defining the role of NK cell receptors in the control of HIV-1 will offer novel therapeutic targets to manipulate and improve future HIV-1 vaccine strategies.

Published: 13 September 2012

doi:10.1186/1742-4690-9-S2-P173

Cite this article as: Jost et al:: Tim-3-mediated signaling in NK cells may be modulated by increased Galectin- 9 expression in HIV-1 infection. Retrovirology 2012 9(Suppl 2):P173.

Submit your next manuscript to BioMed Central and take full advantage of:

- Convenient online submission

- Thorough peer review

- No space constraints or color figure charges

- Immediate publication on acceptance

- Inclusion in PubMed, CAS, Scopus and Google Scholar

- Research which is freely available for redistribution

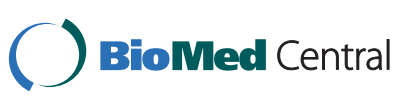

(c) 2012 Jost et al; licensee BioMed Central Ltd. This is an Open Access article distributed under the terms of the Creative Commons Attribution License (http://creativecommons.org/licenses/by/2.0), which permits unrestricted use, distribution, and reproduction in any medium, provided the original work is properly cited. 